\section{高強度コンクリートの強度推定 に関する研究}

$$
\begin{aligned}
& \text { ーマスコンクリート模擬部材を用いた } \\
& \text { 各種非破壊試験方法に関する実験的検 } \\
& \text { 討一 }
\end{aligned}
$$

\section{STUDY ON ESTIMATING STRENGTH OF HIGH STRENGTH CONCRETE}

- Experimental studies of several non-destructive test for concrete using mock-up mass concrete specimen -

$\begin{array}{ll}\text { 大池 武 }-* 1 & \text { 日野吉彦— } \\ \text { 池内俊之 } & * 2 \\ * 3 & \text { 安富陽子 }\end{array}$

キーワード :

マスコンクリート, 高強度コンクリート, 強度推定, 非破壊試験, 模擬部材，回帰分析，寄与率

\section{Keywords:}

Mass concrete, High strength concrete, Estimating strength, Non-destructive test, Mock-up specimen, Regression analysis, Contribution ratio

\section{Takeshi OHIKE \\ Toshiyuki IKEUCHI $-*$ \\ Yoshihiko HINO - $* 2$}

The purpose of this study is to establish strength estimation method for high strength construction concrete whose strength is below $100 \mathrm{~N} / \mathrm{mm}^{2}$ using non-destructive test. Experimental studies of non-destructive test and concrete core strength are carried out and the following conclusions are drawn in this research. It is confirmed that several multi-regression analysis using combinations of several single non-destructive test results are examined in this study. The analysis shows that the combination of rebound-hummer method and elastic-wave propagation method gives more accurate estimation equations in the concrete strength range of over $60 \mathrm{~N} / \mathrm{mm}^{2}$ than single rebound-hummer method.

\section{1.はじめに}

近年、コンクリート構造物の健全性に関する社会的な説明責任を 果たす為、既設構造物のコンクリート強度を定量的に把握すること は非常に重要となっている。現在、構造体コンクリートの圧縮強度 の非破壊試験方法としてはリバウンドハンマーによる反発度法 ${ }^{1)}$ が 一般に採用されている。その適用範囲は強度 $60 \mathrm{~N} / \mathrm{mm}^{2}$ 程度が上限と されているが、現実的には超高層建築物などで設計基準強度が $60 \mathrm{~N} / \mathrm{mm}^{2}$ を上回るものもある。一方、 $60 \mathrm{~N} / \mathrm{mm}^{2}$ を超える高強度域での 非破壊試験方法に関寸る研究例 ${ }^{2)}$ は豊富であるとは言えない現状も ある。

このような状況を踏まえ、本研究は、構造体コンクリート強度 $100 \mathrm{~N} / \mathrm{mm}^{2}$ 程度までの高強度コンクリートの非破壊試験による強度推 定方法を確立することを最終的な目的としている。

筆者らは、これまでに、管理用供試体強度と各種非破壊試験の関 係 ${ }^{3)}$ 、壁模擬部材を用いた非破壊試験への鉄筋の影響 ${ }^{4)}$ 、壁模擬部 材における各種非破壞試験とコア強度の関係等 ${ }^{5), 6)}$ について報告を 行ってきており、引続きマスコンクリート壁を模擬した部材 (以下、 模擬部材）を用いた各種非破壊試験とコア強度の関係について研究 を進めている。本報告では、この研究の材齢 3 年までの試験結果か ら、非破壊試験結果とコア供試体圧縮強度の関係において明らかに なった成果を報告する。

\section{2. 実験概要}

実験の要因は、コンクリートの調合（水結合材比 (W/B)）とし、超 高強度域を包含できるように $\mathrm{W} / \mathrm{B}=30 \%$ (想定設計基準強度 $60 \mathrm{~N} / \mathrm{mm}^{2}$ )、
$\mathrm{W} / \mathrm{B}=40 \%\left(\right.$ 同 $\left.45 \mathrm{~N} / \mathrm{mm}^{2}\right) 、 \mathrm{~W} / \mathrm{B}=50 \%($ 同 30N/mm²) の 3 水準としている。

\section{1 模擬部材}

模擬部材の概要を表 1 に示寸。

実験の要因とした水結合材比毎に模擬部材を製作している。ただ

し、W/B=40\%の模擬部材は 2 体とし、合計 4 体を製作し実験を行って

\begin{tabular}{|c|c|}
\hline 項目 & 備考 \\
\hline 調合 (W/B) & 水結合材比: $30 \%, 40 \%, 50 \%$ \\
\hline 模擬部材製作数 & $\begin{array}{l}\text { W/B=30\%: } 1 \text { 体 } \\
\text { W/B=40\% : } 2 \text { 体 } \\
\text { W/B=50\%: } 1 \text { 体 }\end{array}$ \\
\hline 模擬部材寸法 & 幅 $2.325 \mathrm{~m}$ 、高さ $2.25 \mathrm{~m}$ 、厚さ $1.3 \mathrm{~m}$ \\
\hline 配筋 & 横筋：D38@225 縦筋：外側D38@310 \\
\hline コンクリート打込み季節 & 冬期 \\
\hline 暴露場所 & 東京都清瀬市 \\
\hline
\end{tabular}
いる。

模擬部材のコンクリートの打込みは、冬期（2006 年 1 月中旬）に

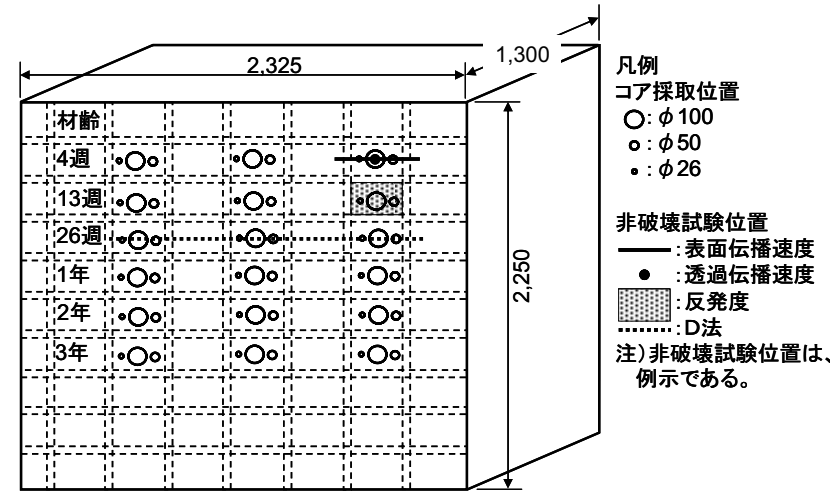

図 1 模擬部材形状・法

\footnotetext{
(㹯大林組技術研究所技術開発サポート部 課長

（干 204-8558 東京都清瀬市下清戸 4-640)

(烌大林組原子力本部技術部 副主査・修士（工学）

関西電力㑣)土木建築室 リーダー・・博士 (工学)

*4 関西電力(烌土木建築室
}

Section Manager, R\&D Promotion Dept., Technical Research Institute, Obayashi Corporation

Deputy Manager, Engineering Dept., Nuclear Facilities Division, Obayashi Corporation, M. Eng.

*3 Assistant Manager, Office of Civil Engineering and Architecture, The Kansai Electric Power Co., Inc., Ph. D.

4 Office of Civil Engineering and Architecture, The Kansai Electric Power Co., Inc. 
行っている。なお、模擬部材は、構造体からその一部を切り出した 状沉を再現するため、コンクリート打込みから 2 週間、測定面およ び裏面を除く 4 面（上面、底面、両側面）を厚さ $20 \mathrm{~cm}$ の断熱材で覆 い、養生している。また、模擬部材の暴露場所は、東京都清瀬市で ある。

図 1 に、模擬部材の形状 - 寸法、配筋を示寸。また、図中には直 径 $100 \phi$ コア (以後、標準コア) と直径 $50 \phi$ コア、直径 $26 \phi コ ア$ (以 後、小径コア）の採取位置も併せて示している。なお、配筋は非破 壊試験を実施する面にのみ配置しており、かぶり厚さは $96 \mathrm{~mm}$ である。

\section{2 使用材料とコンクリートの調合}

使用材料を表 2 に示す。想定設計基準強度が最大 $60 \mathrm{~N} / \mathrm{mm}^{2}$ のマス コンクリートであることを考慮して、セメントは中庸熱ポルトラン ドセメントとし、結合材としてフライアッシュを $20 \%$ 内割置換して いる。

実験に用いたコンクリートの調合を表 3 に示す。表 3 にはフレッ シュコンクリートの試験結果も併せて示している。

コンクリートの目標性能は、W/B=40\%と $50 \%$ はスランプ $15 \pm 2.5 \mathrm{~cm}$ 、 空気量 $4.5 \pm 1.5 \%$ W/B $=30 \%$ はスランプフロー $55 \pm 10 \mathrm{~cm}$ 、空気量 4.5 $\pm 1.5 \%$ ある。

\section{3 試験項目および試験方法}

試験項目と試験材齢を表 4 に示す。非破壊試験は、超音波伝播速 度、弾性波伝播速度、反発度としている。微破壊試験として小径コ アの圧縮強度も実施している。なお、非破壊試験は、図 1 に示すコ ア採取位置近傍で実施しており、標準コアと小径コアの供試体採取 位置は、図 2 を標準としている。

標準コアの試験材齢は、材齢 4 週、13 週、26 週、 1 年、 2 年、 3 年の 6 材齢としている。また、模擬部材と同時に作製した円柱供試 体（直径 $100 \phi$ 、標準養生、以後、管理用供試体）は、上記に加え 材齢 3 日、 5 日、1 週についても試験を実施している。

使用機器と試験方法を表 3 に示寸。非破壊試験は、既往の研究 7), 8, 9) などを参考に、複数の手法・機器を採用している。具体的に は、超音波伝播速度 2 機種、弾性波伝播速度 4 方法、反発度法 2 機 種である。各機器の試験方法は、JIS 規格があるものはJIS 規格に 準じることとし、JIS 規格がないものはメーカの推奨測定方法ある いは開発提案による測定方法を採用している。

超音波、弾性波伝播速度は、同一面 2 点間の伝播速度（以後、表 面伝播速度)、表裏壁面間の伝播速度（以後、透過伝播速度）を測定 している。なお、筆者ら ${ }^{4)}$ が壁模擬部材で対象としていた反射波伝 播速度は、模擬部材の壁厚が $1.3 \mathrm{~m}$ と厚いため測定できなかったので 本報告では対象外としている。

弹性波伝播速度には、「地盤の弾性波速度検層方法」10), 11) を応用 し、構造体コンクリートの原位置における動弾性係数を求める D 法 も含めている。この D 法の測定では、図 3 に示すようにセンサー設 置間隔が $50 \mathrm{~cm}$ であることから、1 模擬部材、1 材齢における標準コ ア抜取り位置（水平方向 3 箇所）について 1 デー夕を取得できるの みである。一方、超音波、弾性波ならびに反発度法は、1 本の標準 コア採取位置で 1 個のデータが取得できる。従って、D 法でのデー 夕取得は、超音波伝播速度などの 3 分の 1 になっている。このため、 後述の回帰分析におけるD 法を含めた検討では、標準コア強度、超 音波伝播速度等のデータは、水平方向 3 箇所のデータの平均值を求
表 2 使用材料

\begin{tabular}{|c|c|}
\hline 材料 & 備考 \\
\hline セメント & 中庸熱ポルトランドセメント (密度: $3.21 \mathrm{~g} / \mathrm{cm}^{3}$ ) \\
\hline 水 & 地下水 \\
\hline 細骨材(1) & 砕砂（栃木県栃木市鍋山町産） 密度: $2.66 \mathrm{~g} / \mathrm{cm}^{3}$, 粗粒率: 3.20 \\
\hline 細骨材(2) & 山砂 (千葉県香取郡大栄町産) 密度: $2.59 \mathrm{~g} / \mathrm{cm}^{3}$, 粗粒率: 1.80 \\
\hline 粗骨材 & 硬質砂岩砕石 (埼玉県両神産) 密度: $2.70 \mathrm{~g} / \mathrm{cm}^{3}$, 実積率: $58.8 \%$ \\
\hline フライアッシュ & JIS II 種品(密度: $2.23 \mathrm{~g} / \mathrm{cm}^{3} 、$ 比表面積: $3890 \mathrm{~cm}^{2} / \mathrm{g}$ ) \\
\hline 混和剤 & 高性能AE減水剂(標準型) (ポリカルボン酸系) \\
\hline
\end{tabular}

表 3 コンクリートの調合

\begin{tabular}{|c|c|c|c|c|c|c|c|c|c|c|c|}
\hline \multirow{3}{*}{$\begin{array}{l}\text { 調合 } \\
\text { (W/B) }\end{array}$} & \multirow{3}{*}{\begin{tabular}{|c} 
細骨材 \\
率 \\
$(\%)$ \\
\end{tabular}} & \multirow{2}{*}{\multicolumn{6}{|c|}{ 単位量 $\left(\mathrm{kg} / \mathrm{m}^{3}\right)$}} & \multicolumn{4}{|c|}{ フレッシュコンクリートの性質 } \\
\hline & & & & & & & & \multirow{2}{*}{$\begin{array}{c}\text { スランプ. } \\
\text { スラシプフー } \\
(\mathrm{cm})\end{array}$} & \multirow[b]{2}{*}{$\begin{array}{c}\text { 空気量 } \\
(\%)\end{array}$} & \multirow{2}{*}{$\begin{array}{c}\text { 単位 } \\
\text { 容積 } \\
\text { 質量 } \\
\left(\mathrm{kg} / \mathrm{m}^{3}\right)\end{array}$} & \multirow{2}{*}{$\begin{array}{c}\text { בククリ-1 } \\
\text { 温度 } \\
\left({ }^{\circ} \mathrm{C}\right)\end{array}$} \\
\hline & & 水 & $\begin{array}{l}\text { セx } \\
\text { ント }\end{array}$ & $\begin{array}{c}\text { フライ } \\
\text { Pッシシュ }\end{array}$ & $\begin{array}{c}\text { 細骨 } \\
\text { 材 }\end{array}$ & $\begin{array}{l}\text { 粗骨 } \\
\text { 材 }\end{array}$ & $\begin{array}{c}\text { 混和 } \\
\text { 剤 }\end{array}$ & & & & \\
\hline $50 \%$ & 49. & 16 & 264 & 66 & & 921 & 2.145 & 15 & 4.0 & 2,296 & 10.3 \\
\hline $40 \%$ & 46.6 & 165 & 330 & 83 & 800 & 937 & 2.478 & 17.5 & 4.3 & 2,301 & 10.9 \\
\hline $30 \%$ & 44.5 & 170 & 454 & 113 & 698 & 888 & 7.371 & $48.0 \times 47.5$ & 4.8 & 2,324 & 13.7 \\
\hline
\end{tabular}

表 4 試験項目と試験材齢

\begin{tabular}{|c|c|c|}
\hline & 項目 & 内 容 \\
\hline \multirow{4}{*}{ 試験項目 } & 非破壊試験 & $\begin{array}{l}\text { 超音波伝播速度 (表面伝播速度、透過伝播速度) } \\
\text { 弾性波伝播速度 (表面伝速度、透過伝播速度) } \\
\text { 反発度 }\end{array}$ \\
\hline & 標準コア & 直径 $100 \phi コ ア:$ 圧縮強度、動弹性係数、静弹性係数 \\
\hline & 小径コア & 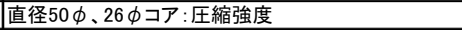 \\
\hline & 管理用供試体 & 圧縮強度、動弾性係数、静弾性係数 \\
\hline \multirow{2}{*}{ 試験材齢 } & 管理用供試体 & 3日、5日、1週、4週、13週、26週、1年、2年、3年 \\
\hline & コア供試体 & 4週、13週、26週、1年、2年、3年 \\
\hline
\end{tabular}

\begin{tabular}{|c|c|c|c|c|c|c|c|c|c|c|c|}
\hline \multirow[t]{3}{*}{ 標準コア } & No.1 & & No.2 & & No.3 & & No.4 & & No.5 & & 8 \\
\hline & \begin{tabular}{|l|l|}
50 & 200 \\
\end{tabular} & 50 & 200 & 50 & 200 & 50 & 200 & 50 & 200 & 50 & \\
\hline & & & & & 1300 & & & & & & \\
\hline
\end{tabular}

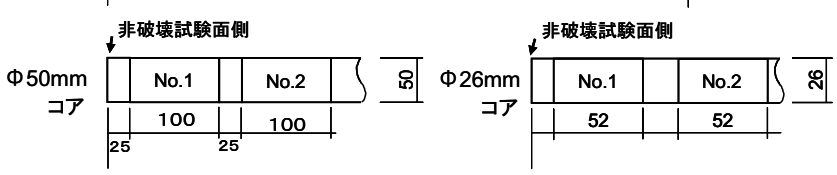

注）標準コアのNo.4,No5は、材齢13週、26週では採取していない 図 2 コア供試体採取位置

表 5 使用機器と試験方法

\begin{tabular}{|c|c|c|c|}
\hline 試験項目 & 略称 & 機器仕様等 & 試験方法 \\
\hline \multirow{2}{*}{ 超音波 } & T社品 & $\begin{array}{l}\text { 探触子:ひび割れ·音速センサ } \\
\text { 振動数: } 28 \mathrm{~Hz} \text { (パルス型電圧) } \\
\end{array}$ & メ一カ一推奨測定方法 \\
\hline & H社品 & $\begin{array}{l}\text { 探触子: ステップ関数型探触子 } \\
\text { 振動数: 広帯域周波数 (ステップ型電圧) }\end{array}$ & メ一カ一推奨測定方法 \\
\hline \multirow{4}{*}{ 弾性波 } & T法 & $\begin{array}{l}\text { 探触子: 厚さセンサ } \\
\text { 振動数: } 2 \text { 8Hzの擬似広帯域波 }\end{array}$ & メ一カ一推奨測定方法 \\
\hline & H法 & $\begin{array}{l}\text { 打撃具: } \phi 10 \mathrm{~mm} \text { 鋼球 } \\
\text { 振動数: } 10 \mathrm{kHz} \text { 程度 } \\
\text { 受信センサ: 広帯域AEセンサ }\end{array}$ & 開発提案測定方法 \\
\hline & I法 & $\begin{array}{l}\text { 打撃具: } \phi 9.5 \mathrm{~mm} \text { 鋼球 } \\
\text { 振動数: 最大 } 30 \mathrm{kHz} \text { 程度 } \\
\text { 受信センサ:圧電センサ } \\
\end{array}$ & ASTM C1383-04 \\
\hline & D法 & $\begin{array}{l}\text { 打撃具: ハンマー 周波数: } 1 \text { 和 } 2 \mathrm{kz} \text { 程度 } \\
\text { 信センサ:圧電型加速度センサ }\end{array}$ & $\begin{array}{l}\text { 開発提案測定方法 } \\
\text { (P波速度(側線方向打撃)， } \\
\text { S波速度(側線と直行方向打 } \\
\text { 撃)から動弾性係数を推定) }\end{array}$ \\
\hline \multirow{2}{*}{ 反発度 } & SH法 & シュミットハンマー & JIS A 1155 \\
\hline & SRH法 & シュミットロックハンマー & JIS A 1155に準じる \\
\hline 圧縮強度 & - & $\begin{array}{l}3000 \mathrm{kN} \text { 万能試験機 (標準コア) } \\
200 \mathrm{kN} \text { 試験機 (小径コア) }\end{array}$ & \begin{tabular}{|l} 
JIS A 1107 \\
小径コアはツクトコアリング協会法
\end{tabular} \\
\hline 動弾性係数 & - & 共鳴振動法非破壊試験機 & JIS A 1127 \\
\hline 静弾性係数 & - & コンプレッソメーター & JIS A 1149 \\
\hline
\end{tabular}

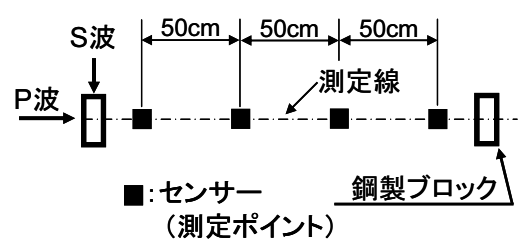

図 3 D 法測定方法

めて検討している。

また、反発度法は、一般的なリバウンドハンマー（SH 法）に加え、 岩盤の圧縮強度、静弾性係数の非破壊試験に用いられるリバウンハ 
ンマー（SRH 法）も加えている。

\section{3. 実験結果}

\section{1 圧縮強度発現性状}

管理用供試体の圧縮強度発現性状を図 4 に、標準コアのそれを図 5 にそれぞれ示す。なお、図 5 では、標準コアの強度は水平方向 3 箇所の平均值をプロットしている。なおかつ、W/B $=40 \%$ 模擬部材のプ ロットは、2 模擬部材の平均值としている。

管理用供試体の強度発現は、全調合とも材齢の経過に伴い順調な 強度発現を示しているが、材齢 1 年以降の強度増進は小さく、材齢 2 年以降は横ばい状態にある。標準コアの強度発現は、ほぼ管理用 供試体と同様なことが言える。ただし、強度レベルは管理用供試体 に比べやや小さい。また、標準コア強度のバラッキは、管理用供試 体のそれに比べ大きくなる傾向が見られている。

図 6 と図 7 には、材齢 4 週 と材齢 3 年の模擬部材断面内の強度分 布を示す。プロットの方法は図 5 と同様である。

これらの図から、W/B=40\%、W/B=30\%の場合は、初期材齢では W/B= $50 \%$ と同様に断面内の強度差はないが、長期材齢の材齢 3 年では 表面部の標準コア強度が高く、表面に比べて断面内部の強度増進は 小さくなる傾向が見られている。一方、W/B=50\%の場合は、材齢が 異なっても断面内の強度差は見られず、コンクリートの調合、材齢 によって断面内の強度分布に相違があることがわかる。この傾向は、 文献 ${ }^{12)}$ で指摘される傾向と同じである。このように、コンクリート 強度が高強度になるほど構造体コンクリートの断面内には強度分布 が生じることがわかる。

\section{2 圧縮強度と動弾性係数の関係}

管理用供試体圧縮強度と動弾性係数の指数関数による単回帰分析 結果を図 8 に示す。同様に、指数関数による標淮コアの断面平均コ ア強度（1 箇所）と動弾性係数の単回帰分析結果を図 9 に示寸。こ れらの図には 95\%信頼区間を併せて示している。なお、これ以降の 回帰分析は材齢 3 年までに得られた全てのデータを対象としている。 管理用供試体圧縮強度と動弾性係数の関係は、寄与率（決定係数） で 0.975 と極めて高い相関関係にあることがわかる。一方、標準コ ア強度と動弾性係数の関係は、管理用供試体のそれに比べると小さ くなるものの、寄与率で 0.772 と高い相関関倸にある。一般にコン クリートの圧縮強度と動弾性係数の間には高い相関関係が認められ ており ${ }^{13)}$ 、本実験で、圧縮強度が $100 \mathrm{~N} / \mathrm{mm}^{2}$ 程度の超高強度域におい ても両者の関係を確認することができたと考える。

動弾性係数は超音波伝播速度および弾性波伝播速度と密接な関係 にあることは周知である。また、反発度に関しても圧縮強度と相関 関係にある。従って、超音波あるいは弾性波伝播速度や反発度は、 動弾性係数と同様に高強度コンクリートの強度推定の有力な手段と なりうると考えられる。また、一般的に超音波伝播速度と動弾性係

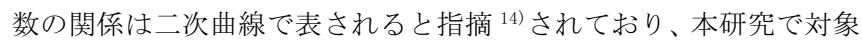
としている高強度域では、文献 ${ }^{14)}$ 等のデータからほぼ直線関係に あると判断している。これより、超音波伝播速度などは、動弾性係 数とコンクリート強度との関係のように指数関数で近似できると考 えられる。また、反発度とコンクリート強度との関係も同様に指数 関数で近似することができる。以上から、以降では超音波と弾性波 の伝播速度および反発度に関しては、対応するコア強度を自然対数
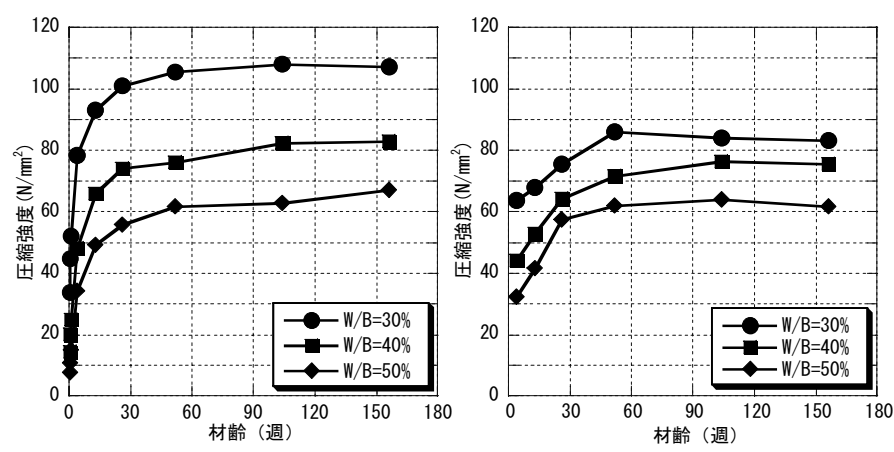

図 4 強度発現性状(管理用供試体)

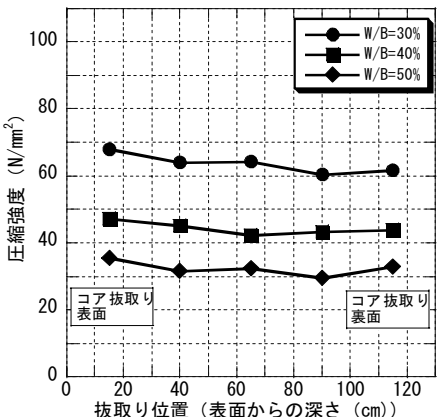

図 5 強度発現性状（標準コア供試体）

図 6 断面内強度分布 (材齢 4 週)
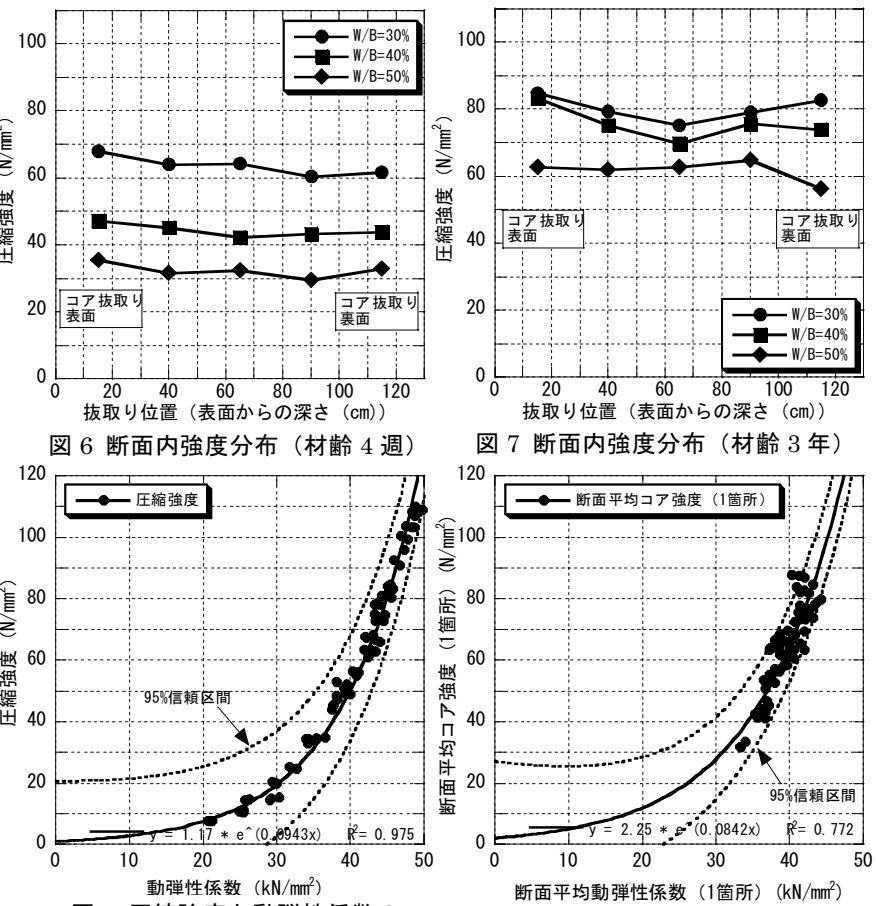

図 7 断面内強度分布 (村㱓 3 年)

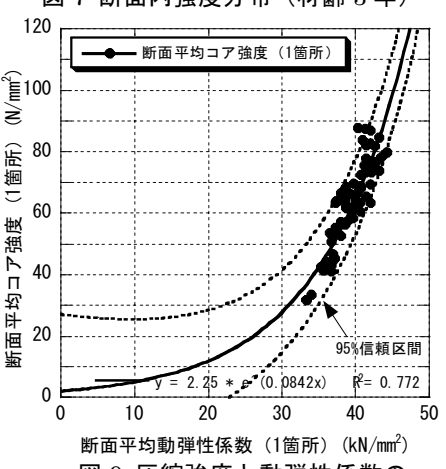

図 9 圧縮強度と動弾性係数の

関係（標準コア供試体）

表 6 単回帰分析結果 (寄与率)

\begin{tabular}{|c|c|c|c|c|c|}
\hline & \multirow{2}{*}{$\begin{array}{c}\text { 非破買検査 } \\
\text { 手法 }\end{array}$} & \multicolumn{2}{|c|}{$\begin{array}{l}\text { 標準コア採取 } \\
\text { 1箇所 }\end{array}$} & \multicolumn{2}{|c|}{$\begin{array}{c}\text { 標準コア採取 } \\
\text { 3箇所平均 }\end{array}$} \\
\hline & & $\begin{array}{l}\text { 断面平均 } \\
\text { コア強度 } \\
\text { (1箇所) }\end{array}$ & $\begin{array}{c}\text { 表面部 } \\
\text { コア強度 } \\
\text { (1箇所) }\end{array}$ & $\begin{array}{l}\text { 断面平均 } \\
\text { コア強度 } \\
\text { (3箇所) }\end{array}$ & $\begin{array}{l}\text { 表面部 } \\
\text { コア強度 } \\
\text { (3箇所) }\end{array}$ \\
\hline \multirow{4}{*}{$\begin{array}{l}\text { 超音波 } \\
\text { 伝播速度 }\end{array}$} & T社品表面伝播速度 & 0.025 & 0.046 & 0.030 & 0.055 \\
\hline & $\mathrm{T}$ 社品透過伝播速度 & 0.925 & 0.876 & 0.947 & 0.922 \\
\hline & H社品表面伝播速度 & 0.008 & 0.003 & 0.008 & 0.002 \\
\hline & H社品透過伝播速度 & 0.946 & 0.891 & 0.967 & 0.936 \\
\hline \multirow{6}{*}{$\begin{array}{l}\text { 弾性波 } \\
\text { 伝播速度 }\end{array}$} & H法表面伝播速度 & 0.019 & 0.031 & 0.028 & 0.055 \\
\hline & H法透過伝播速度 & 0.393 & 0.364 & 0.433 & 0.405 \\
\hline & I法表面伝播速度 & 0.015 & 0.017 & 0.056 & 0.063 \\
\hline & D法P波速度 & - & - & 0.529 & 0.583 \\
\hline & D法S波速度 & - & - & 0.398 & 0.447 \\
\hline & D法推定動弾性 & - & - & 0.432 & 0.484 \\
\hline \multirow{2}{*}{ 反発度 } & SH法 & 0.734 & 0.690 & 0.759 & 0.716 \\
\hline & SRH法 & 0.836 & 0.788 & 0.862 & 0.827 \\
\hline \multirow{2}{*}{$\begin{array}{c}\text { 小径コア } \\
\text { 強度 }\end{array}$} & $50 \phi コ ア$ & 0.891 & 0.884 & 0.913 & 0.921 \\
\hline & $26 \phi コ ア$ & 0.658 & 0.647 & 0.765 & 0.786 \\
\hline
\end{tabular}

に変数変換して、直線近似させることとする。

\section{3 単回帰分析結果}

単回帰分析は、断面平均コア強度（図 2 に示した同一標準コアか ら採取したコア供試体 5 体の平均值）と非破壊試験を実施した表面 部コア強度 (図 2 の No. 1 コア供試体の強度) を従属変数として実施 している。また、標準コア強度は、2.3 で示したように標準コア採 取位置毎の場合（以後、1 箇所）と、水平方向 3 箇所平均值の場合 
（以後、3 箇所）の 2 ケースで扱っている。なお、標準コア強度は 前述の通り自然対数に变数変換して回帰分析を行っている。

単回帰分析結果における寄与率を一覧として表 6 に示す。

単回帰分析における寄与率は、標準コア採取 1 箇所に比べ 3 箇所 平均のほうが大きくなっている。これは、平均值を用いることでば らつきが小さくなっているためと考えられる。

\section{(1) 超音波伝播速度}

表 6 から、超音波の表面伝播速度と標準コア強度（1 箇所）との 関係は、 $\mathrm{T}$ 社、 $\mathrm{H}$ 社共に、断面平均コア強度（1 箇所）、表面部コア 強度（1 箇所）のいずれとも相関関係は小さい結果となっている。 一方、透過伝播速度と断面平均コア強度（1箇所）との相関関係は、 $\mathrm{T}$ 社、 $\mathrm{H}$ 社共に、極めて高い相関関係にあることがわかる。 $\mathrm{H}$ 社透過 伝播速度と断面平均コア強度（1 箇所）の関係を図 10 に一例として 示す。

\section{（2）弾性波伝播速度}

表 6 から、弾性波の表面伝播速度と標準コア強度（1 箇所）の関 係は、H 法、I 法の表面伝播速度に関しては、超音波法と同様に、断 面平均コア強度（1 箇所）、表面部コア強度（1 箇所）のいずれとも 相関関係は小さい結果となっている。H 法の透過伝播速度、D 法の P 波、S 波速度、推定動弾性係数は、表面伝播速度に比べれば高い寄 与率となっており、相関関係が認められる。D 法の P 波速度と断面 平均コア強度（3 箇所）の関係を図 11 に一例として示す。

\section{(3) 反発度}

SH 法反発度と断面平均コア強度（1 箇所）との関係を図 12 に示 す。表 6 ならびに図 12 から、寄与率が 0.734 と比較的良好な相関関 係にあることがわかる。SH 法の強度推定はばらつきがあるものの低 強度域での構造体コンクリートの強度推定に多用されていることは 周知の通りである。一方、文献 ${ }^{15}$ )で指摘されるように、反発度の頭 打ちは見られるが、標準コア強度を自然対数に変数変換して、直線 近似させることで高強度域でも低強度域と同程度の精度で強度推定 が可能であると考えられる。

また、SRH 法反発度と断面平均コア強度（1 箇所）との関係を図 13 に示寸。表 6 ならびに図 13 から、SRH 法は寄与率が 0.836 と SH 法より高い断面平均コア強度 ( 1 箇所) との相関関係を示している。 このように SRH 法反発度は、SH 法に比べ高強度域でのばらつきが小 さい傾向にあり、強度推定の一つの有効な手段となりうる結果を示 している。

\section{（4）小径コア}

$50 \phi$ 小径コア強度と断面平均コア強度（1 箇所）との関係を図 14 に示す。断面平均コア強度（1 箇所）、表面部コア強度（1 箇所）と の関係は、表 6 ならびに図 14 から、寄与率で 0.89 程度と極めて高 い相関関係にあることがわかる。

これより、50 $\phi$ 小径コア強度による構造体コンクリートの強度推 定は、高い推定精度を確保できると言える。また、JIS A 1107 では 採取するコアの直径は、粗骨材最大寸法の 3 倍以下としてはならな いことが規定されているが、今回の結果は、採取するコアの直径は 粗骨材の最大寸法の 2 倍程度であっても、構造体コンクリートの評 価が可能であることを示しているものと考える。

$26 \phi$ 小径コア強度と断面平均コア強度（1 箇所）との関係を図 15 に示寸。断面平均コア強度（1 箇所）、表面部コア強度（1 箇所）と
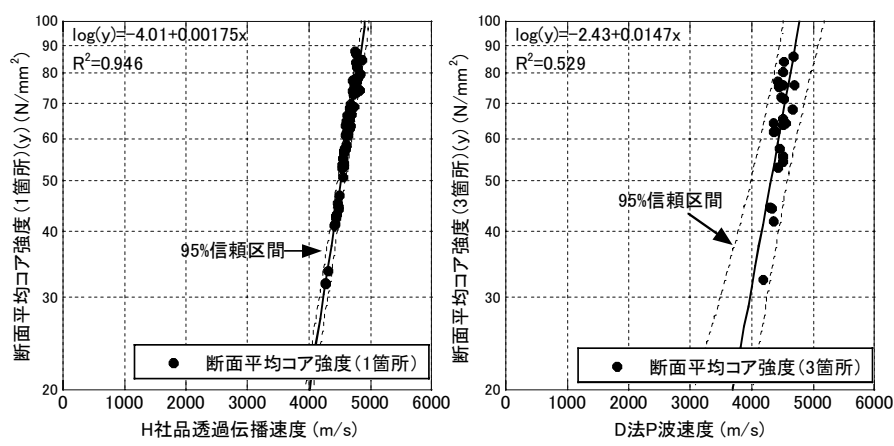

図 $10 \mathrm{H}$ 社品透過伝播速度と断 面平均コア強度 (1 箇所) の関係

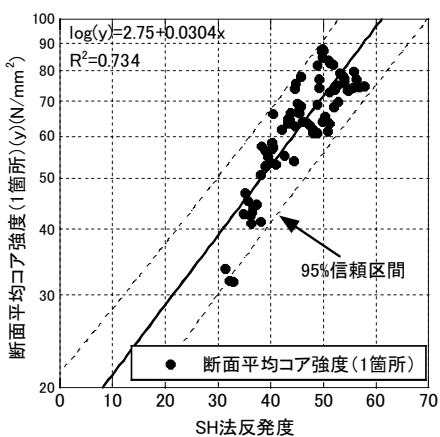

図 $12 \mathrm{SH}$ 法反発度と断面 平均コア強度（1箇所）の関係

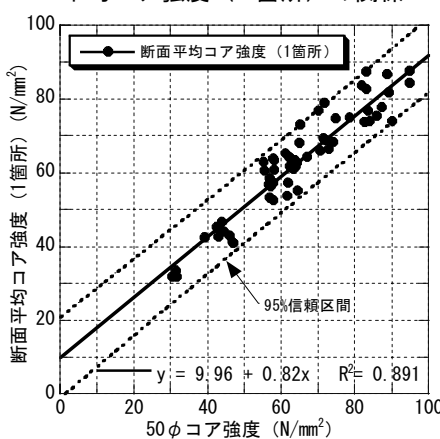

図 $1450 \phi$ 小径コア強度と断面 平均コア強度（1 箇所）の関係

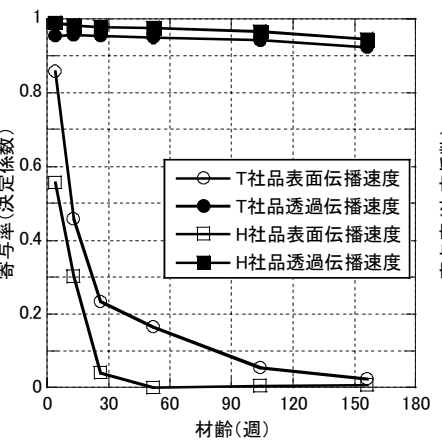

図 16 寄与率の推移 （超音波法）
図 $11 \mathrm{D}$ 法 $\mathrm{P}$ 波速度と断面平均コ ア強度（3 箇所）の関係

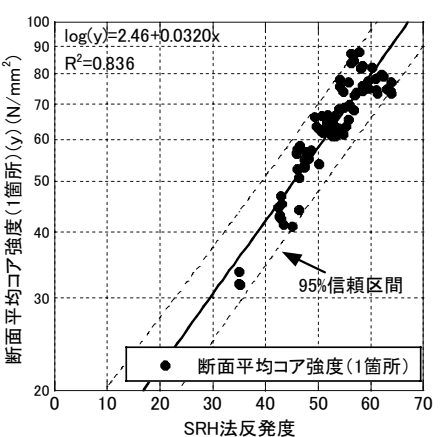

図 $13 \mathrm{SRH}$ 法反発度と断面 平均コア強度（1 箇所）の関係

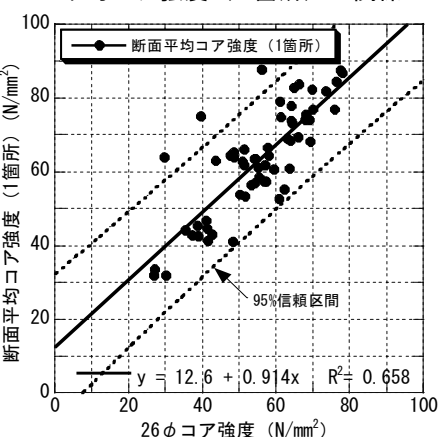

図 1526 ф小径コア強度と断面 平均コア強度（1箇所）の関係

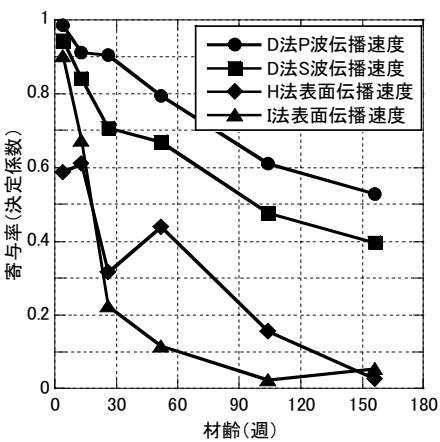

図 17 寄与率の推移

(弾性波法)

の関係は、表 6 ならびに図 15 から、寄与率で 0.65 程度と比較的良 好な相関関係にあることがわかる。

なお、26 $\phi$ 小径コアの圧縮強度試験は、建築センターの建築物等 の保全技術・技術審査証明を取得した「ソフトコアリング」の試験 方法に従って強度試験を実施している。標準コア強度との相関関係 は、試験結果の值をそのまま用いて検討している。また、本研究で は審査証明の適用範囲である $60 \mathrm{~N} / \mathrm{mm}^{2}$ を超え約 $100 \mathrm{~N} / \mathrm{mm}^{2}$ までの超高 強度域までその適用を試みている。前述のように、標準コア強度と 
は比較的良好な相関関係を示しているものの、技術審查証明を超え る範囲での適用はさらに検討する必要があるものと考える。

\section{4 単回帰分析における寄与率の推移}

強度推定に用いる非破壊試験手法は、構造体コンクリートとの相 関が高く、かつ材齢が変化してもその相関が変化しないものが望ま しいと考えられる。

主な非破壊試験手法の材齢の経過に伴う断面平均コア強度に対す る寄与率の推移を図 16〜図 19 に示す。ここで、各材齢の寄与率は、 材齢 4 週から当該材齢までの全てのデータを対象とした単回帰分析 結果による寄与率である。

これらの図から、全体的に材齢を経ることによって寄与率が下が る傾向にあることがわかる。この原因として、材齢の経過に伴う各 種試験結果のばらつきなどにより単回帰分析における寄与率を下げ るデータが増加されるためと考えられるが、その傾向は手法毎に異 なっている。

本模擬部材実験における寄与率の推移を見ると、超音波表面伝播 速度（図 16）と断面平均コア強度（1 箇所）との相関関係は、材齢 の経過に伴い寄与率が極端に低下している。これは、コンクリート 表面の乾燥に伴い、超音波の伝播速度が影響を受けたためと考えら れる。

弾性波伝播速度（図 17）の寄与率の低下は、測定手法により大き く異なっている。H 法、I 法は、超音波表面伝播速度と同様に、比較 的初期材齢から極端に低下している。これに対し D 法の P 波、S 波 速度は、材齢の経過に伴い徐々に低下し、低下の度合いも超音波表 面伝播速度、H 法、I 法に比べ小さいことがわかる。これら弾性波伝 播速度の寄与率の低下も超音波表面伝播速度と同様な原因が考えら れるが、D 法の場合は、コンクリート中のより内部を伝播する波の 速度を計っていると考えられため、他の手法に比べ低下の度合いが 小さくなっていると考える。

反発度法（図 18）もコンクリート表面の乾燥の影響を受けるが、 寄与率の低下は小さく良好な相関関係を維持している。一方、コン クリート表面の乾燥の影響が少ない超音波透過伝播速度（図 16）、 $50 \phi$ 小径コア強度（図 19）は材齢の経過に伴う寄与率の低下も少な く、極めて高い寄与率を維持している。また、2 6 \%小径コア強度は、 材齢 1 年前後で寄与率が回復するように見えるが、 $50 \phi$ コアに比べ 寄与率の低下が大きくなっている。これは、26 $\phi$ という小径コアで あるがために強度試験実施技術者の熟練度の影響が考えられる。

\section{5 複合法による重回帰分析結果}

反発度と音速の複合法による強度推定については、これまでにも いくつかの研究例 16), 17) があり、日本建築学会の「鉄筋コンクリート 造建築物の品質管理および維持管理のための試験方法」 ${ }^{18)}$ にいて も非破壊試験方法の一つとして整備されている。ここでは、反発度 法に超音波伝播速度、弾性波伝播速度を組み合わせることによる複 合法による強度推定の精度の向上に対する効果について検討する。 なお、ここで分析に用いたデータは、2. 3 で述べたように水平方向 3 䇢所の平均值である。

複合法による重回帰分析結果の寄与率の一覧を表 7 に示す。表中 の括弧内はSH 法、SRH 法のそれぞれの単回帰による寄与率からの増 分である。また、一例として推定強度と断面平均コア強度（3 箇所） の関係で整理した SH 法反発度と H 社品表面伝播速度、H 社品透過伝

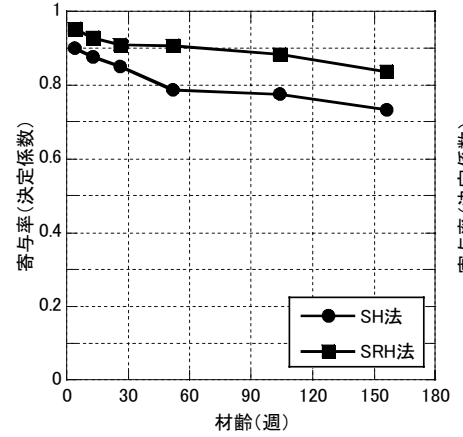

図 18 寄与率の推移 (反発度法)

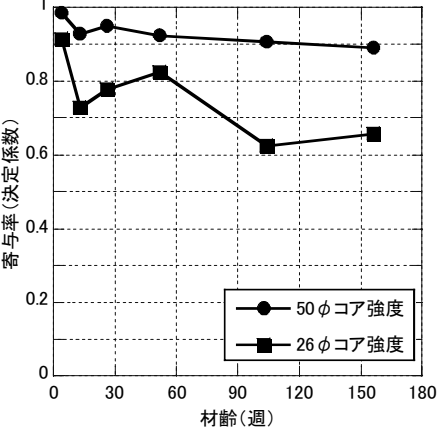

図 19 寄与率の推移 (小径コア法)
表 7 複合法による重回帰分析結果 (寄与率)

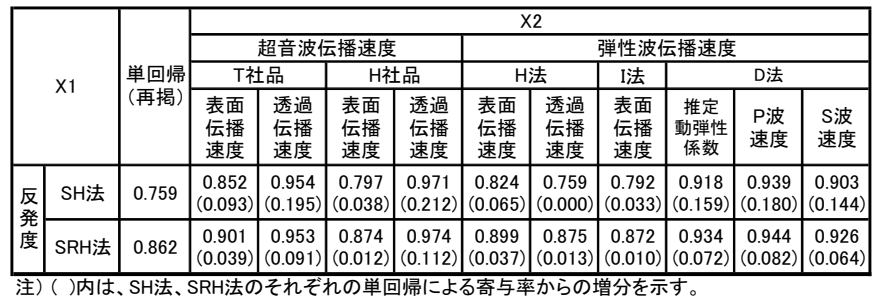

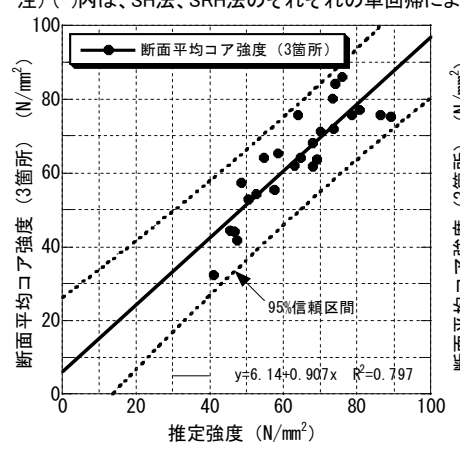

図 $20 \mathrm{SH}$ 法反発度 $+\mathrm{H}$ 社品表面伝播 速度の組合せによる推定強度と断 面平均コア強度 (3 箇所) の関係

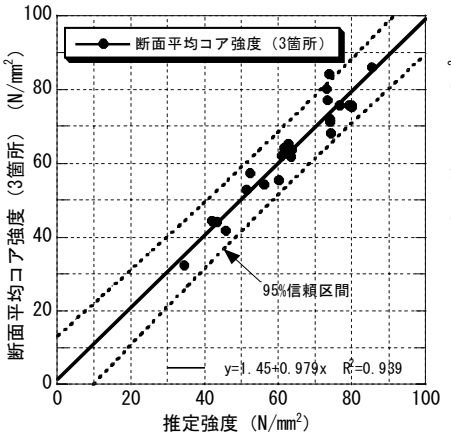

図 $22 \mathrm{SH}$ 法反発度 $+\mathrm{D}$ 法 $\mathrm{P}$ 波速度 の組合せによる推定強度と断面平 均コア強度（3 箇所）の関係

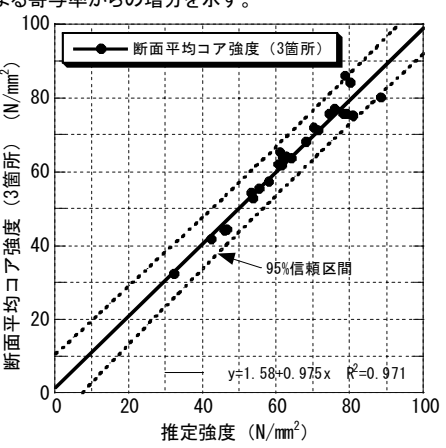

図 $21 \mathrm{SH}$ 法反発度 $+\mathrm{H}$ 社品透過伝播 速度の組合せによる推定強度と断面 平均コア強度 (3 箇所) の関係

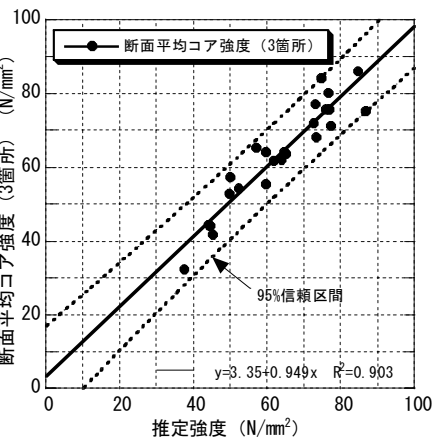

図 $23 \mathrm{SH}$ 法反発度 $+\mathrm{D}$ 法 $\mathrm{S}$ 波速度 の組合せによる推定強度と断面平 均コア強度（3 箇所）の関係
播速度、D 法 $\mathrm{P}$ 波速度、D 法 $\mathrm{S}$ 波速度との組み合わせの結果を図 20 〜図 23 に示寸。

表 7 から、複合法による強度推定の精度の向上に対する効果を寄 与率の増分で評価すると、次のような特徵が見られる。

超音波伝播速度の場合、文献 ${ }^{16)}$, 17) などのように複合法とすること でコンクリート強度との相関関係を高められると指摘されているが、 本実験の範囲において SH 法反発度と表面伝播速度との組み合わせ では、SH 法の単回帰寄与率からの増分は 0. 038 0.093 とあまり大 きくなく複合法の効果がほとんど期待できないことがわかる。一方、 SH 法反発度と透過伝播速度との組み合わせでは、SH 法も単回帰寄与 
率からの増分は 0.195〜0.212 と表面伝播速度との組み合わせに比 べると大きいが、超音波の透過伝播速度は元々、単回帰において寄 与率が高く、複合法の効果とは言えない。これらの傾向は、SRH 法 反発度の組み合わせにおいても同様である。

弾性波伝播速度の場合、H 法、I 法については、SH 法の単回帰寄 与率からの増分は、0 0.065 と超音波の表面伝播速度との組み合わ せと同等であり、複合法の効果がほとんど期待できない。一方、SH 法反発度と D 法推定動弹性係数、D 法 P 波速度、D 法 $\mathrm{S}$ 波速度におけ る反発度の単回帰寄与率からの増分は $0.144 \sim 0.180$ と寄与率の増 分が比較的大きい。ただし、H 法、I 法に対する傾向は、SRH 法反発 度との組み合わせにおいても同様であるが、D 法推定動弹性係数、D 法 $\mathrm{P}$ 波速度、 $\mathrm{D}$ 法 $\mathrm{S}$ 波速度における反発度の単回帰寄与率からの増 分は 0.064〜0.082 と SH 法反発度との組み合わせよりも寄与率の増 分が小さい。

表 6 と表 7 を対比すればわかるように、組み合わせる非破壊検査 方法の単回帰寄与率の大小関係と複合法の効果の大小関係はほぼ同 じ関係にあるが、H 法の透過伝播速度と D 法のように、単回帰寄与 率が同程度でも複合法の効果は同程度ではない場合もある。

以上から、単回帰寄与率が高いものの実構造物での実用上の制約 条件が多い透過伝播速度を除いた場合、強度レベル $60 \mathrm{~N} / \mathrm{mm}^{2}$ を超え る高強度コンクリートの強度推定において反発度法と組合せる非破 壊検查方法として単回帰寄与率が $0.40 \sim 0.53$ 程度のD法を採用する ことによって、より推定精度が高い強度推定式が構築できる可能性 は高いと考える。

\section{4.まとめ}

構造体コンクリート強度 $100 \mathrm{~N} / \mathrm{mm}^{2}$ 程度までの高強度コンクリー トの模擬部材を用いた各種非破壊試験方法と標準コア強度の関係に ついて実験検討を行った。本実験の範囲で明らかになったことを以 下に示寸。

1）一般にコンクリートの圧縮強度と動弾性係数の間には高い相関 関係が認められており、本実験で、圧縮強度が $100 \mathrm{~N} / \mathrm{mm}^{2}$ 程度の超高 強度域においても両者の関係を確認することができた。

2）超音波伝播速度において、採用した 2 機種とも、表面伝播速度は 標準コア強度との相関関係が見られなかったが、透過伝播速度は標 準コア強度との相関関係が極めて高いことがわかった。

3）弾性波伝播速度において、採用した手法のうちD 法は標準コア強 度との相関関係が認められた。

4）反発度法の SH 法、SRH 法は、 $60 \mathrm{~N} / \mathrm{mm}^{2}$ を超える範囲においても標 準コア強度と比較的良好な相関関係にあることが確認できた。

5）微破壞試験法の小径コア法において、50 $\phi$ 小径コア強度が標準コ ア強度と極めて高い相関関係にあることがわかった。一方、26 小 径コア強度は、標準コア強度と比較的良好な相関関係を示している ものの、技術審査証明を超える範囲での適用には更なる検討が必要 であることがわかった。

6）単回帰分析による寄与率の推移は、非破壊検查手法によって異な り、超音波表面伝播速度などのように、材齢の経過に伴い急激に寄 与率が小さくなるもの、逆に、超音波透過伝播速度などのように、 材齢が経過しても高い相関関係にあるものがあった。

7）複合法による重回帰分析の結果、反発度法とD 法の組み合わせは、
反発度法単独に比ベ、強度レベル $60 \mathrm{~N} / \mathrm{mm}^{2}$ を超える高強度コンクリ ートの強度推定においてより推定精度が高い強度推定式が構築でき る可能性が高いことを示すことができた。

\section{謝辞}

本研究を行うにあたり、京都大学名誉教授の渡邊史夫先生に多大 なるご指導を賜りました。ここに深く感謝いたします。

\section{参考文献}

1）コンクリート強度推定のための非破壊試験方法マニュアル, 日本建築学 会, 1983.

2）例えば、立見、中田、河谷：衝撃弾性波を用いたコンクリートの非破壊圧 縮強度推定法に関する研究, シンポジウム コンクリート構造物の非破壊 検査への期待, pp. $37-48,2003.7$

3）大池、伏見ほか：高強度コンクリートの強度推定に関する研究（その 1 管 理用供試体強度と各種非破壊検査の関係），日本建築学会大会学術講演梗 概集（関東）A1，pp. 371-372，2006.9

4）大池、池内ほか: 高強度コンクリートの強度推定に関する研究 (その 2 壁 模擬部材を用いた非破壊検查の伝播速度に現れる鉄筋の影響) , 日本建築 学会大会学術講演梗概集 (九州) A1，pp. 229-230，2007.8

5) 中山、池内ほか: 高強度コンクリートの強度推定に関する研究 (その 3 壁 模擬部材における各種非破壊検査とコア強度の関係), 日本建築学会大会 学術講演梗概集（東北）A1，pp. 837-838，2009.8

6) 大池、池内ほか : 高強度コンクリートの強度推定に関する研究 (その 4 壁 模擬部材における反発度と複合法による強度推定), 日本建築学会大会学 術講演梗概集（東北）A1，pp. 839-840，2009.8

7）立見ほか: 衝撃弹性波を用いたコンクリートの破壞圧縮強度推定法に関す る研究, シンポジウム コンクリート構造物の非破壊検査への期待, pp. $37-48,2003.7$

8）尼崎：コンクリートの非破壊検査方法 (原理と手法) -コンクリート強度, 弹性係数一, コンクリート工学, Vol，27, No. 3, pp. 31-35, 1989.

9）立見ほか: 衝撃弹性波によるコンクリートの圧縮強度推定方法に関する基 礎的研究 一骨材の種類、養生方法および含水率の違いが弾性波速度に及 ぼす影響一, 日本建築学会構造系論文集 第 598 号, pp. 13-20, 2005.12

10）（社）地盤工学会, 地盤調查法改訂編集委員会編集 : 地盤調查の方法と解 説, 2004.

11）野畑、宮本、板橋ほか：原子炉建屋における動弾性係数の測定方法につ いて (その 1$) \sim(そ の 3 ）$, 日本建築学会大会学術講演梗概集（近畿） B2, pp. 1099-1104, 1996. 9

12）尾崎、大藤ほか：コンクリートの長期物性モニタリング試験, 日本建築 学会技術報告集 第 13 号, pp. 9-14，2001.7

13）例えば、高野: コンクリートの動的弾性係数と強度との関係, セメント 技術年報 $\mathrm{V}$, pp. 363-371, 1951.

14）例えば、十代田ほか：条件の異なるコンクリートの音速と動弹性係数と の関係一非破壞試験による構造体コンクリートの品質検査法の総合的検 討（その 2) - , 日本建築学会構造系論文集 第 527 号, pp. 15-19, 2000.1

15）菅、岩淵ほか: 高強度コンクリートに対応したテストハンマーの開発 (そ の 1 ) , (その 2 ), 日本建築学会大会学術講演梗概集（北陸） A1, pp. 643-646, 2002.8

16）十代田、野崎、小林：実大モデルによる超音波法、反発度法および複合法 の検討 一非破壊試験による構造体コンクリートの強度推定法一, 日本建 築学会構造系論文集 第428号, pp. 25～33，1991. 10

17）野崎、十代田、小林：超音波法、反発度法および複合法の既存建物への 適用 非破壊試験による構造体コンクリートの強度推定法 その 2 , 日 本建築学会構造系論文集 第 444 号, pp. 1 6, 1993.2

18）鉄筋コンクリート造建築物の品質管理および維持管理のための試験方法, 日本建築学会, 2007.

[2009 年 10 月 20 日原稿受理 2010 年 1 月 8 日採用決定］ 